\title{
Anoxybacillus gonensis sp. nov., a moderately thermophilic, xylose-utilizing, endospore-forming bacterium
}

\author{
Ali Osman Belduz, Sabriye Dulger and Zihni Demirbag \\ Karadeniz Technical University, Faculty of Arts and Sciences, Department of Biology, \\ 61080 Trabzon, Turkey
}

Ali Osman Belduz

belduz@ktu.edu.tr

\begin{abstract}
Seven closely related xylanolytic, thermophilic bacilli were isolated from mud and water samples from the Gonen and Diyadin hot springs, respectively located in the Turkish provinces of Balikesir and Agri. On the basis of morphology and biochemical characteristics, one of the isolates, designated strain $\mathrm{G} 2^{\top}$, was studied further. Strain $\mathrm{G} 2^{\top}$ is a xylanolytic, sporulating, Grampositive, rod-shaped bacterium. The isolate is a thermophilic (optimum temperature for growth, $55-60^{\circ} \mathrm{C}$ ), facultative anaerobe that grows on a wide range of carbon sources, including glucose, starch, xylose and mannitol. It expressed a high level of xylose isomerase activity on xylose and also on glucose. 16S rRNA gene sequence analysis showed that this isolate resembled Anoxybacillus flavithermus DSM $2641^{\top}$ (>97\% similarity), but 16S-23S rDNA internally transcribed spacer polymorphism PCR showed variation between DSM $2641^{\top}$ and isolate G2 ${ }^{\top}$. However, it is also known that analysis of $16 \mathrm{~S}$ rRNA gene sequences may be insufficient to distinguish between some species. In DNA-DNA hybridization, thermophilic isolate $\mathrm{G} 2^{\top}$ showed relatedness of $53.4 \%$ to A. flavithermus and about $45.0 \%$ to Anoxybacillus pushchinoensis, indicating that it is distinct at the species level. On the basis of the evidence presented, it is proposed that strain $\mathrm{G} 2^{\top}\left(=\mathrm{NCIMB} 13933^{\top}=\mathrm{NCCB}^{\top} 100040^{\top}\right)$ be designated as the type strain of Anoxybacillus gonensis sp. nov.
\end{abstract}

It is now over a century since thermophiles were first reported (Miquel, 1888). Over the years, a number of sporeforming thermophiles have been reported, mainly in the genera Bacillus and Clostridium (Guagliardi et al., 1996).

In this study, we isolated some thermophilic bacilli from the Gonen and Diyadin hot springs, respectively located in the Turkish provinces of Balikesir and Agri. On the basis of preliminary experiments, a representative strain appeared to differ from other thermophilic bacilli with respect to the utilization of xylose; it was therefore characterized further. Xylose isomerase is an intracellular enzyme that catalyses the conversion of D-xylose to D-xylulose. Its practical significance stems from its ability to isomerize D-glucose to D-fructose. Therefore, this enzyme is often referred to as glucose isomerase and is widely used in industry for the production of high-fructose corn syrup.

The present paper describes the isolation, morphological,

Published online ahead of print on 31 January 2003 as DOI 10.1099/ ijs.0.02473-0.

Abbreviation: ITS, internally transcribed spacer.

The GenBank accession number for the 16S rRNA gene sequence of Anoxybacillus gonensis G2 ${ }^{\top}$ is AY 122325 . physiological and biochemical profiles and 16S rRNA sequence of this strain and the results of DNA-DNA hybridization with close relatives and proposes that it represents a novel species of the genus Anoxybacillus (Pikuta et al., 2000), Anoxybacillus gonensis sp. nov.

\section{Isolation of strains}

Seven Gram-positive rods were isolated from mud and water samples from the Gonen and Diyadin hot springs. The water temperature of these hot springs is around $70{ }^{\circ} \mathrm{C}$. After collection, mud and water samples were used immediately for enrichment in nutrient broth at $60-70{ }^{\circ} \mathrm{C}$. Oneday-old enrichment cultures were repeatedly subcultured in $10 \mathrm{ml}$ nutrient broth and streaked on agar plates to obtain separate colonies. The purity of the isolates was assessed by colony morphology and microscopy. After 48 h growth on nutrient agar medium, colonies of strain $\mathrm{G} 2^{\mathrm{T}}$ were small, cream, irregularly shaped with rough edges and $2-3 \mathrm{~mm}$ in diameter. Light microscopy revealed that cells of the strain were rod-shaped, Gram-positive and motile, measuring $0.75 \times 5 \cdot 0 \mu \mathrm{m}$.

\section{Biochemical and nutritional characteristics}

Utilization of organic compounds as sole carbon sources was tested in basal medium (5 ml) supplemented with $0 \cdot 5 \%$ 
(w/v) of the following compounds, which had been separately sterilized as stock solutions: glucose, mannitol, mannose, sucrose, xylose, arabinose, lactose, raffinose, starch, glycogen and rhamnose. Incubation was carried out at $60^{\circ} \mathrm{C}$. The strain was nutritionally versatile and used a wide variety of carbohydrates when grown on basal medium. It grew on glucose, glycogen, raffinose, sucrose, xylose and mannitol (Table 1). Anaerobic growth was tested in anaerobic agar medium. Strain $\mathrm{G}^{\mathrm{T}}$ grew well aerobically, but was facultatively anaerobic.

The ranges of temperature $\left(35-75^{\circ} \mathrm{C}\right)$ and $\mathrm{pH}(5 \cdot 5-10 \cdot 5)$ for growth were determined in nutrient broth medium. Media were adjusted to the initial $\mathrm{pH}$ indicated with either $1 \mathrm{M} \mathrm{NaOH}$ or $1 \mathrm{M} \mathrm{HCl}$. Strain $\mathrm{G}^{\mathrm{T}}$ grew well at $40-70^{\circ} \mathrm{C}$, with optimum growth at $55-60^{\circ} \mathrm{C}$, and grew well at $\mathrm{pH} 6 \cdot 0-10 \cdot 0$, with optimum growth at $\mathrm{pH} 7 \cdot 5-8 \cdot 0$. Catalase and oxidase were detected by the method of Cowan \& Steel (1974). Strain G2 ${ }^{\mathrm{T}}$ is catalase- and oxidase-positive.

\section{Salt and antibiotic sensitivity}

Four replicate sets of nutrient broth were prepared containing 1, 2, 3, 4, 5 or $7 \% \mathrm{NaCl}$. Growth of the isolate at different salt concentrations was tested using nutrient broth as the organic substrate and using a control broth without any $\mathrm{NaCl}$ supplementation. Growth was inhibited in the presence of $\mathrm{NaCl}$ concentrations above $4 \%$ and in the presence of chloramphenicol $\left(25 \mu \mathrm{g} \mathrm{ml}^{-1}\right)$, ampicillin $\left(25 \mu \mathrm{g} \mathrm{ml}^{-1}\right)$, streptomycin sulphate $\left(25 \mu \mathrm{g} \mathrm{ml}^{-1}\right)$ and tetracycline $\left(12 \cdot 5 \mu \mathrm{g} \mathrm{ml}^{-1}\right)$. The optimal $\mathrm{NaCl}$ concentration for growth was $2 \%$.

\section{Spore formation}

The formation of spores was tested by microscopic observation of both liquid cultures and single colonies of the isolates from agar plates after different incubation periods. Incubation for 1-2 days was required before spore formation became detectable on agar plates. Light microscopy revealed that strain $\mathrm{G} 2^{\mathrm{T}}$ was a sporulating bacillus. It formed terminal spherical endospores.

\section{5 rRNA gene sequence analysis}

The 16S rRNA gene was selectively amplified from purified genomic DNA by using oligonucleotide primers designed to anneal to conserved positions in the $3^{\prime}$ and $5^{\prime}$ regions of bacterial 16S rRNA genes. The forward primer, UNI16S-L (5'-ATTCTAGAGTTTGATCATGGCTTCA-3'), corresponded to positions 11-26 of the Escherichia coli 16S rRNA, while the reverse primer, UNI16S-R (5'-ATGGTACCGTGTGACGGGCGGTGTTGTA-3'), corresponded to the complement of positions 1411-1393 of E. coli 16S rRNA (Brosius et al., 1978). PCR conditions were according to Beffa et al. (1996). The PCR product was cloned into pGEM$\mathrm{T}$ and then the 16S rRNA gene sequence was determined with an Applied Biosystems model 373A DNA sequencer, using the ABI PRISM cycle-sequencing kit. A sequence consisting of about $1400 \mathrm{nt}$ of the $16 \mathrm{~S}$ rRNA gene of strain

Table 1. Physiological and biochemical properties of strains of Anoxybacillus gonensis sp. nov. and Anoxybacillus flavithermus DSM $2641^{\top}$

Cells of all strains are sporulating rods. All strains show anaerobic growth and oxidase activity, are negative for utilization of lactose and rhamnose and positive for utilization of starch, sucrose, glucose and mannitol. ND, No data; w, weak growth.

\begin{tabular}{|c|c|c|c|c|c|c|c|c|}
\hline Characteristic & \multicolumn{7}{|c|}{ Anoxybacillus gonensis sp. nov. } & $\begin{array}{l}\text { Anoxybacillus } \\
\text { flavithermus } \\
\text { DSM } 2641^{\mathrm{T}}\end{array}$ \\
\hline \multicolumn{9}{|c|}{ Temperature for growth $\left({ }^{\circ} \mathrm{C}\right)$ : } \\
\hline Range & $37-70$ & $37-70$ & $37-70$ & $37-70$ & $37-70$ & $37-70$ & $40-70$ & $30-72$ \\
\hline Range & $5 \cdot 5-9 \cdot 5$ & $5 \cdot 5-9 \cdot 5$ & $5 \cdot 5-10 \cdot 0$ & $5 \cdot 5-9 \cdot 5$ & $5 \cdot 5-9 \cdot 5$ & $5 \cdot 5-9 \cdot 5$ & $6 \cdot 0-10 \cdot 0$ & $5 \cdot 5-9 \cdot 0$ \\
\hline Optimum & $7 \cdot 0$ & $7 \cdot 0$ & $7 \cdot 0$ & $7 \cdot 0$ & $7 \cdot 0$ & $7 \cdot 0$ & $7 \cdot 5-8 \cdot 0$ & $7 \cdot 0$ \\
\hline Tolerance of $\mathrm{NaCl}(\%)$ & $4 \cdot 0$ & $4 \cdot 0$ & $4 \cdot 0$ & $4 \cdot 0$ & $3 \cdot 5$ & $4 \cdot 0$ & $4 \cdot 0$ & $2 \cdot 5$ \\
\hline \multicolumn{9}{|c|}{ Carbon sources (basal medium): } \\
\hline Glycogen & + & + & + & + & + & + & + & - \\
\hline Fructose & + & + & + & + & + & + & + & $\mathrm{ND}$ \\
\hline Nitrate reduction & + & + & + & + & + & + & + & - \\
\hline Hydrolysis of gelatin & + & - & - & + & - & - & + & - \\
\hline
\end{tabular}


$\mathrm{G} 2^{\mathrm{T}}$ was determined. The sequence was compared with the $16 \mathrm{~S}$ rDNA sequences of some representatives of the Bacillus group by using PHYLIP version 3.5 (Felsenstein, 1989). Phylogenetic analysis revealed a clustering with Anoxybacillus flavithermus DSM $2641^{\mathrm{T}}$ ( $97 \%$ sequence similarity). These sequences differed by 7-16\% from sequences of species of the genus Bacillus and can therefore be distinguished as a separate genus. The sequence of strain $\mathrm{G} 2^{\mathrm{T}}$ showed 96,93 and $86 \%$ similarity, respectively, to sequences from Anoxybacillus pushchinoensis DSM $12423^{\mathrm{T}}$, Saccharococcus caldoxylosilyticus DSM $12041^{\mathrm{T}}$ and Alicyclobacillus acidocaldarius.

\section{PCR amplification of intergenic 16S-23S rDNA sequences}

Primers FGPS1490-72 (5'-TGCGGCTGGATCCCCTCCTT-3'; positions 1521-1541 of the E. coli $16 \mathrm{~S}$ rRNA gene sequence) and FGPL132'-38 (5'-CCGGGTTTCCCCATTCGG-3'; positions 114-132 of the E. coli $23 \mathrm{~S}$ rRNA gene sequence) were used for amplification of intergenic 16S-23S rDNA sequences. PCR conditions were according to Riffard et al. (1998). As shown in Fig. 1, all seven novel strains showed a faint band of about $300 \mathrm{bp}$, but only A2, A6 and G2 ${ }^{\mathrm{T}}$ had the same pattern, with A4, A5, A7 and A9 showing a different banding pattern. However, the internally transcribed spacer (ITS) patterns of all the novel strains were different from those of Anoxybacillus flavithermus DSM $2641^{\mathrm{T}}$ and S. caldoxylosilyticus DSM $12041^{\mathrm{T}}$; therefore, $\mathrm{G} 2^{\mathrm{T}}$ is different from these strains.

\section{G + C content analysis and DNA-DNA hybridization studies}

After extraction and purification of the DNA (Johnson, 1985), the G+C content was determined from the denaturation temperature in $0.5 \times$ SSC. Denaturation profiles were followed at $260 \mathrm{~nm}$ using a thermoprogrammable spectrophotometer (Jenway $6105 \mathrm{UV} / \mathrm{V}$ is spectrophotometer) in accordance with the principles of Mandel \& Marmur (1968). The $\mathrm{G}+\mathrm{C}$ content of this strain is

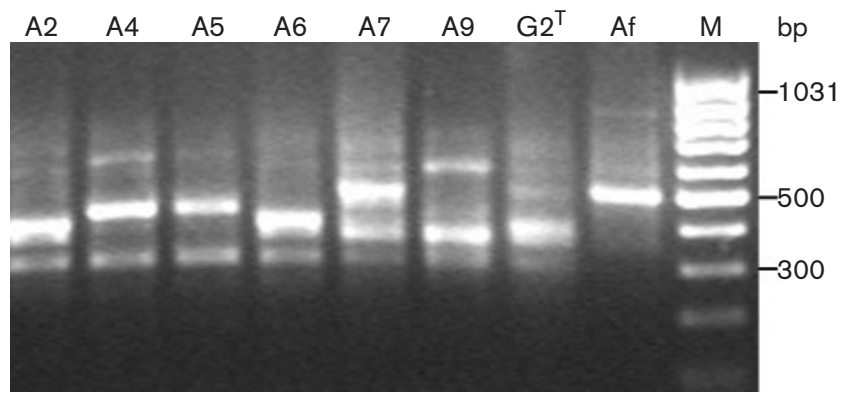

Fig. 1. ITS-PCR analysis of strains $G 2^{\top}, A 2, A 4, A 5, A 6, A 7$, A9 and Anoxybacillus flavithermus DSM $2641^{\top}$ (Af). Lane M, $100 \mathrm{bp}$ ladder.
Table 2. DNA-DNA relatedness (\%)

\begin{tabular}{|lccc|}
\hline Strain & G2 $^{\text {T }}$ & A4 & A7 \\
\hline${\text { Anoxybacillus pushchinoensis DSM } 12423^{\mathrm{T}}}$ & $45 \cdot 0$ & $\mathrm{ND}$ & $\mathrm{ND}$ \\
Strain A4 & $82 \cdot 3$ & - & $88 \cdot 2$ \\
Strain A7 & $77 \cdot 9$ & $88 \cdot 2$ & - \\
Anoxybacillus flavithermus DSM 2641 $^{\mathrm{T}}$ & $53 \cdot 4$ & $45 \cdot 4$ & $52 \cdot 3$ \\
\hline
\end{tabular}

$57 \mathrm{~mol} \%$, which is lower than that of Anoxybacillus flavithermus DSM $2641^{\mathrm{T}}$.

DNA was isolated by chromatography on hydroxyapatite. DNA-DNA hybridization was determined at the Deutsche Sammlung von Mikroorganismen und Zellkulturen (DSMZ), Braunschweig, Germany, as described by De Ley et al. (1970), with the modifications described by Huß et al. (1983) and Escara \& Hutton (1980). A Gilford System model 2600 spectrophotometer equipped with a Gilford model 2527-R thermoprogrammer and plotter was used. Renaturation rates were computed with the TRANSFER.BAS program (Ahmad et al., 2000). DNA-DNA hybridization studies were performed among G2 ${ }^{\mathrm{T}}, \mathrm{A} 4, \mathrm{~A} 7$ and Anoxybacillus flavithermus DSM $2641^{\mathrm{T}}$ and between $\mathrm{G}^{\mathrm{T}}$ and Anoxybacillus pushchinoensis DSM $12423^{\mathrm{T}}$ (Table 2).

\section{SDS-PAGE analysis}

Extracts from cells growing actively on nutrient broth medium were obtained according to the method of Belduz et al. (1993). The protein concentration in the extracts was measured according to the method of Bradford (1976) and $40 \mu \mathrm{g}$ crude extract was loaded per lane. Electrophoresis on $12 \%$ SDS-PAGE was carried out as described by Laemmli (1970). Proteins were stained in a solution that contained Coomassie brilliant blue R-250 (0·125\%), methanol (50\%) and acetic acid (10\%) for 2-4 h and then visualized by destaining in a solution of $5 \%$ methanol/7\% acetic acid. The electrophoretic patterns of soluble cellular proteins, as determined by SDS-PAGE (Fig. 2), showed that $\mathrm{G} 2^{\mathrm{T}}$ is not similar to Anoxybacillus flavithermus DSM $2641^{\mathrm{T}}$, Anoxybacillus pushchinoensis DSM $12423^{\mathrm{T}}$ or S. caldoxylosilyticus DSM $12041^{\mathrm{T}}$, and $\mathrm{G} 2^{\mathrm{T}}$ therefore does not belong to any of these species. The other six novel strains were examined; SDS-PAGE analysis showed the similarity of these strains to $\mathrm{G}^{\mathrm{T}}$ (Fig. 2).

\section{Cellular fatty acids}

Cultivation, harvesting, preparation and analysis of cellular fatty acid methyl esters from whole-cell fatty acids from strains G2 ${ }^{\mathrm{T}}$, A2, A4, A6, A7, A9 and Anoxybacillus flavithermus DSM $2641^{\mathrm{T}}$ were performed according to the method described in the Sherlock Microbial Identification System manual (version 4.0; MIDI). The fatty acid methyl esters of strain $\mathrm{G}^{\mathrm{T}}$ and the other six strains and Anoxybacillus flavithermus DSM $2641^{\mathrm{T}}$ were identified by comparing the commercial M17H10 database using the MIS software package, version 3.8 (Microbial ID). The cellular 


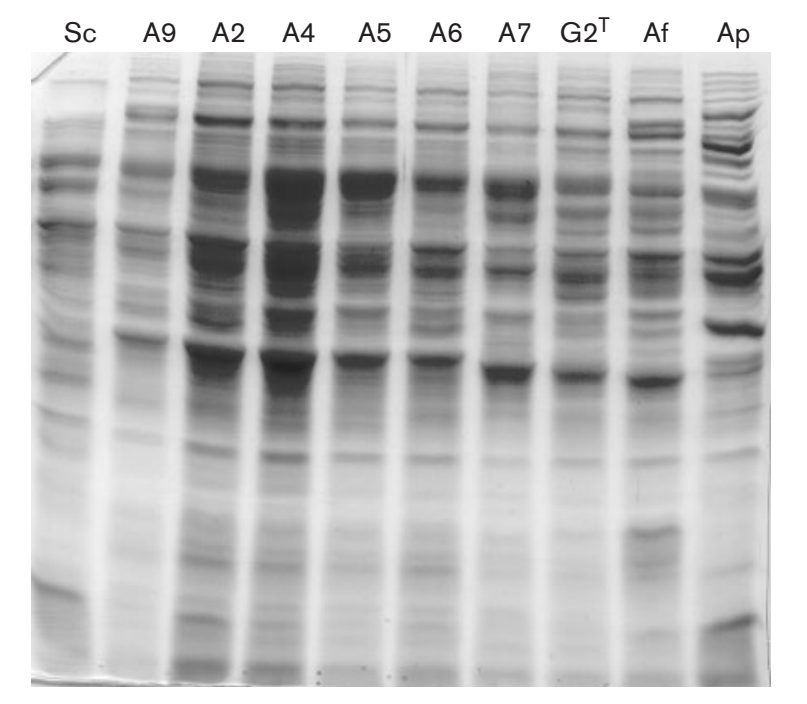

Fig. 2. SDS-PAGE whole-cell protein profiles of strains $A 2$, A4, A5, A6, A7, A9 (strains of Anoxybacillus gonensis sp. nov. isolated from Diyadin hot spring), Anoxybacillus gonensis $\mathrm{G}^{\top}{ }^{\top}$, Anoxybacillus flavithermus DSM $2641^{\top}$ (lane Af); Anoxybacillus pushchinoensis DSM $12423^{\top}$ (Ap) and Saccharococcus caldoxylosilyticus DSM $12041^{\top}$ (Sc).

fatty acid profiles of the seven novel strains and Anoxybacillus flavithermus DSM $2641^{\mathrm{T}}$ are shown in Table 3; the fatty acid profiles of the novel strains were very similar, with $\mathrm{C}_{15: 0}$ iso as the main fatty acid (62-68\%). Strain $\mathrm{G}^{\mathrm{T}}$ also resembled Alicyclobacillus acidocaldarius on the basis of fatty acid profiles, but the morphological and biochemical properties and 16S rRNA gene sequence of $\mathrm{G} 2^{\mathrm{T}}$ do not resemble those of this bacterium.

\section{Enzyme assays}

Activity of xylose isomerase was determined in extracts of $\mathrm{G}^{\mathrm{T}}$. For this experiment, cells were cultivated in LuriaBertani medium containing either $0.5 \%$ xylose or $0.5 \%$ glucose in a $500 \mathrm{ml}$ flask at $60^{\circ} \mathrm{C}$. Cells were lysed by adding

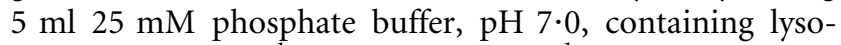
zyme $\left(0 \cdot 2 \mathrm{mg} \mathrm{ml}^{-1}\right)$, DNase $\left(5 \mu \mathrm{g} \mathrm{ml}^{-1}\right)$ and Triton X-100 $(0 \cdot 1 \%)$ per $\mathrm{g}$ (wet weight) cells. The mixture was stirred gently for $2-3 \mathrm{~h}$ at room temperature. The lysate was centrifuged (20000 $g$ for $20 \mathrm{~min}$ ) and the pellet was used for the enzyme assay. The protein content of the lysate was measured according to the method of Bradford (1976). Xylose isomerase activity was then measured as described by Lee et al. (1990). The enzyme activity was determined as 0.78 and $0.5 \mathrm{U}$ (mg protein $)^{-1}$ at $60^{\circ} \mathrm{C}$ on xylose and glucose, respectively, from crude cell lysate.

Initial studies indicated that $\mathrm{G}^{\mathrm{T}}{ }^{\mathrm{T}}$ was a member of Bacillus cluster 5, as defined by Ash et al. (1991). On the basis of genotypic and phenotypic properties, the isolate can be distinguished from other Bacillus species described. Despite the morphological observations that clearly class this bacterium as a Bacillus, its closest relative, on the basis of

Table 3. Fatty acids of strains of Anoxybacillus gonensis sp. nov.

Values are percentages of total fatty acids.

\begin{tabular}{|c|c|c|c|c|c|c|c|c|}
\hline \multirow[t]{2}{*}{ Fatty acid } & \multicolumn{7}{|c|}{ Anoxybacillus gonensis sp. nov. } & \multirow{2}{*}{$\begin{array}{l}\text { Anoxybacillus } \\
\text { flavithermus } \\
\text { DSM } 2641^{\mathrm{T}}\end{array}$} \\
\hline & $\mathrm{A} 2$ & A4 & A5 & A6 & A7 & A9 & $\mathrm{G}{ }^{\mathrm{T}}$ & \\
\hline $\mathrm{C}_{13: 0}$ iso & - & $0 \cdot 16$ & - & $0 \cdot 29$ & $0 \cdot 21$ & $0 \cdot 26$ & - & - \\
\hline $\mathrm{C}_{14: 0}$ iso & $0 \cdot 72$ & $1 \cdot 09$ & $1 \cdot 03$ & $0 \cdot 41$ & $0 \cdot 38$ & $0 \cdot 53$ & $1 \cdot 25$ & - \\
\hline $\mathrm{C}_{14: 0}$ & $1 \cdot 10$ & $0 \cdot 93$ & $0 \cdot 99$ & $1 \cdot 16$ & 0.69 & $1 \cdot 19$ & $1 \cdot 18$ & $1 \cdot 96$ \\
\hline $\mathrm{C}_{14: 0}$ iso $3-\mathrm{OH}$ & - & $0 \cdot 32$ & $0 \cdot 44$ & - & $0 \cdot 32$ & - & - & $54 \cdot 85$ \\
\hline $\mathrm{C}_{15: 0}$ iso & $62 \cdot 13$ & $64 \cdot 55$ & $66 \cdot 36$ & $68 \cdot 06$ & $64 \cdot 76$ & $63 \cdot 07$ & $65 \cdot 19$ & $4 \cdot 02$ \\
\hline $\mathrm{C}_{15: 0}$ anteiso & $2 \cdot 50$ & $2 \cdot 76$ & $2 \cdot 86$ & $2 \cdot 66$ & $2 \cdot 17$ & $2 \cdot 14$ & $2 \cdot 64$ & $1 \cdot 18$ \\
\hline $\mathrm{C}_{15: 0} \omega 5 c$ & - & $0 \cdot 41$ & - & - & - & - & - & - \\
\hline $\mathrm{C}_{15: 1} \omega 5 c$ & - & - & $0 \cdot 25$ & - & - & - & - & - \\
\hline $\mathrm{C}_{15: 0}$ & $0 \cdot 90$ & $1 \cdot 65$ & $1 \cdot 45$ & $0 \cdot 75$ & $1 \cdot 06$ & $0 \cdot 96$ & $1 \cdot 12$ & $2 \cdot 97$ \\
\hline $\mathrm{C}_{16: 0}$ iso & $5 \cdot 46$ & $5 \cdot 54$ & $4 \cdot 80$ & $2 \cdot 94$ & $3 \cdot 60$ & $2 \cdot 34$ & $5 \cdot 99$ & $11 \cdot 13$ \\
\hline$C_{16: 0}$ & $3 \cdot 86$ & $1 \cdot 89$ & $1 \cdot 98$ & $3 \cdot 10$ & $2 \cdot 94$ & $2 \cdot 98$ & $2 \cdot 38$ & - \\
\hline $\mathrm{C}_{17: 1} \omega 5 c$ & $2 \cdot 04$ & $3 \cdot 87$ & $4 \cdot 28$ & $1 \cdot 87$ & $2 \cdot 03$ & $1 \cdot 42$ & $2 \cdot 63$ & - \\
\hline $\mathrm{C}_{17: 0}$ anteiso $\mathrm{A}$ & - & $0 \cdot 93$ & - & - & - & - & $0 \cdot 82$ & $17 \cdot 74$ \\
\hline $\mathrm{C}_{17: 1}$ anteiso $\mathrm{A}$ & - & - & $1 \cdot 03$ & $0 \cdot 39$ & $0 \cdot 47$ & $0 \cdot 44$ & - & - \\
\hline $\mathrm{C}_{17: 0}$ iso & $15 \cdot 67$ & $10 \cdot 57$ & $9 \cdot 16$ & $13 \cdot 56$ & $16 \cdot 41$ & $10 \cdot 02$ & $11 \cdot 96$ & $6 \cdot 15$ \\
\hline $\mathrm{C}_{17: 0}$ anteiso & $4 \cdot 10$ & $2 \cdot 76$ & $2 \cdot 47$ & $3 \cdot 36$ & $3 \cdot 56$ & $2 \cdot 47$ & $3 \cdot 29$ & - \\
\hline $\mathrm{C}_{18: 0}$ & - & - & - & - & - & $0 \cdot 64$ & - & - \\
\hline $\mathrm{C}_{19: 0}$ 10-methyl & - & - & - & - & - & $10 \cdot 66$ & - & - \\
\hline
\end{tabular}


16S rRNA sequence analysis, is Anoxybacillus flavithermus DSM $2641^{\mathrm{T}}$.

Stackebrandt \& Goebel (1994) reached the conclusion that strains belonging to the same genus that exhibit less than $97 \%$ 16S rRNA gene sequence similarity should be considered members of different species. However, it is also known that analysis of $16 \mathrm{~S}$ rRNA sequences may be insufficient to distinguish between some species (Vandamme et al., 1996). In this study, we determined the $16 \mathrm{~S}$ rRNA gene sequence of $\mathrm{G} 2^{\mathrm{T}}$ and found more than $97 \%$ similarity to that of Anoxybacillus flavithermus. However, we also determined that some physiological, morphological and biochemical characteristics of our isolate differ from those of Anoxybacillus flavithermus DSM $2641^{\mathrm{T}}$. In addition, Daffonchio et al. (1998) showed that the 16S23S ITS of Bacillus cereus are well conserved in terms of length; in contrast, bacilli such as Bacillus licheniformis and Bacillus subtilis have at least two different ITS fingerprints. In this study, we showed that $\mathrm{G}^{\mathrm{T}}$ has a different ITS fingerprint from Anoxybacillus flavithermus DSM $2641^{\mathrm{T}}$ and S. caldoxylosilyticus DSM $12041^{\mathrm{T}}$. As a result of the ITS study, we suggest that our isolate is different from Anoxybacillus flavithermus.

On the basis of 16S rRNA sequence analysis, these thermophilic isolates resemble Anoxybacillus flavithermus, but a DNA-DNA hybridization study performed between $\mathrm{G}^{\mathrm{T}}$ and Anoxybacillus flavithermus showed that this isolate is only $53 \cdot 4 \%$ similar to Anoxybacillus flavithermus. Since the novel isolate was found to be closely related genetically to Anoxybacillus flavithermus, we conclude that our novel isolates belong to the genus Anoxybacillus. The genus has one other species, Anoxybacillus pushchinoensis. In this study, we found $45 \%$ similarity between $\mathrm{G}_{2}{ }^{\mathrm{T}}$ and Anoxybacillus pushchinoensis on the basis of DNA-DNA hybridization. Wayne et al. (1987) suggested that strains of a species show more than $70 \%$ DNA-DNA relatedness, indicating that strain $\mathrm{G}^{\mathrm{T}}$ and Anoxybacillus pushchinoensis represent different species.

On the basis of these data, we suggest that our thermophilic isolate $\left(\mathrm{G} 2^{\mathrm{T}}\right)$ is not related to either Anoxybacillus flavithermus DSM $2641^{\mathrm{T}}$ or Anoxybacillus pushchinoensis DSM $12423^{\mathrm{T}}$ at the species level (in view of threshold value of $70 \%$ recommended by Wayne et al., 1987), and we propose that strain $\mathrm{G}_{2}^{\mathrm{T}}$ should be placed in the genus Anoxybacillus as the type strain a novel species, Anoxybacillus gonensis sp. nov.

On the basis of their morphological, physiological, biochemical and fatty acid profiles and 16S rRNA sequences, the other six novel isolates are strains of Anoxybacillus gonensis. Although there are some differences between A4, A5, A7 and $\mathrm{G}^{\mathrm{T}}{ }^{\mathrm{T}}$ in terms of ITS patterns and total protein profiles, DNA-DNA hybridization also indicated that all seven novel isolates are strains of Anoxybacillus gonensis (Table 2).
Description of Anoxybacillus gonensis sp. nov.

Anoxybacillus gonensis (gon.en'sis. N.L. masc. adj. gonensis pertaining to Gonen, a hot spring in the province of Balikesir, Turkey, where the type strain was isolated).

Cells are rod-shaped, Gram-positive, motile and sporeforming, $0 \cdot 75 \times 5 \cdot 0 \mu \mathrm{m}$. Forms terminal spherical endospores. Colonies are rough and cream in colour. Weakly catalase-positive. Oxidase-positive. Starch and gelatin are hydrolysed. Glucose, glycogen, raffinose, sucrose, xylose, fructose and mannitol are utilized. Nitrate is not reduced to nitrite. Urease, indole and $\mathrm{H}_{2} \mathrm{~S}$ are not produced. Grows in $4 \% \mathrm{NaCl}$ broth. The $\mathrm{pH}$ range for growth is $6 \cdot 0-10 \cdot 0$ (optimum $\mathrm{pH} 7 \cdot 5-8 \cdot 0$ ). The temperature range for growth is $40-70{ }^{\circ} \mathrm{C}$ (optimum $55-60^{\circ} \mathrm{C}$ ). Facultative anaerobe. The $\mathrm{G}+\mathrm{C}$ content of the DNA is $57 \mathrm{~mol} \%$ (by melting temperature).

The type strain, $\mathrm{G}^{\mathrm{T}}\left(=\mathrm{NCIMB} 13933^{\mathrm{T}}=\mathrm{NCCB} 100040^{\mathrm{T}}\right)$, was isolated from Gonen hot spring, Turkey.

\section{Acknowledgements}

This work was supported, in part, by DPT grants 2001K12080010 and KTU 99.111.004.5. A doctoral scholarship to S. D. from the Scientific and Research Council of Turkey is duly acknowledged.

\section{References}

Ahmad, S., Scopes, R. K., Rees, G. N. \& Patel, B. K. C. (2000). Saccharococcus caldoxylolyticus sp. nov., an obligately thermophilic, xylose-utilizing, endospore-forming bacterium. Int $J$ Syst Evol Microbiol 50, 517-523.

Ash, C., Farrow, J. A. E., Wallbanks, S. \& Collins, M. D. (1991). Phylogenetic heterogeneity of the genus Bacillus revealed by comparative analysis of small-subunit-ribosomal RNA sequences. Lett Appl Microbiol 13, 202-206.

Beffa, T., Blanc, M., Lyon, P. F., Vogt, G., Marchiani, M., Fischer, J. L. \& Aragno, M. (1996). Isolation of Thermus strains from hot composts (60 to $80^{\circ} \mathrm{C}$ ). Appl Environ Microbiol 62, 1723-1727.

Belduz, A. O., Lee, E. J. \& Harman, J. G. (1993). Mutagenesis of the cyclic AMP receptor protein of Escherichia coli: targeting positions 72 and 82 of the cyclic nucleotide binding pocket. Nucleic Acids Res 21, 1827-1835.

Bradford, M. M. (1976). A rapid and sensitive method for the quantitation of microgram quantities of protein utilizing the principle of protein-dye binding. Anal Biochem 72, 248-254.

Brosius, J., Palmer, M. L., Kennedy, P. J. \& Noller, H. F. (1978). Complete nucleotide sequence of a $16 \mathrm{~S}$ ribosomal RNA gene from Escherichia coli. Proc Natl Acad Sci U S A 75, 4801-4805.

Cowan, S. T. \& Steel, K. J. (1974). Manual for the Identification of Medical Bacteria, 2nd edn. Cambridge: Cambridge University Press.

Daffonchio, D., Borin, S., Frova, G., Manachini, P. L. \& Sorlini, C. (1998). PCR fingerprinting of whole genomes: the spacers between the $16 \mathrm{~S}$ and $23 \mathrm{~S}$ rRNA genes and of intergenic tRNA gene regions reveal a different intraspecific genomic variability of Bacillus cereus and Bacillus licheniformis. Int J Syst Bacteriol 48, 107-116.

De Ley, J., Cattoir, H. \& Reynaerts, A. (1970). The quantitative measurement of DNA hybridization from renaturation rates. Eur J Biochem 12, 133-142. 
Escara, J. F. \& Hutton, J. R. (1980). Thermal stability and renaturation of DNA in dimethyl sulfoxide solutions: acceleration of the renaturation rate. Biopolymers 19, 1315-1327.

Felsenstein, J. (1989). PHYLIP: phylogeny inference package. (version 3.2). Cladistics 5, 164-166.

Guagliardi, A., Martino, M., laccarino, I., de Rosa, M., Rossi, M. \& Bartolucci, S. (1996). Purification and characterization of the alcohol dehydrogenase from a novel strain of Bacillus stearothermophilus growing at $70^{\circ} \mathrm{C}$. Int J Biochem Cell Biol 28, 239-246.

Huß, V. A. R., Festl, H. \& Schleifer, K. H. (1983). Studies on the spectrophotometric determination of DNA hybridization from renaturation rates. Syst Appl Microbiol 4, 184-192.

Johnson, J. L. (1985). Determination of DNA base composition. Methods Microbiol 18, 1-29.

Laemmli, U. K. (1970). Cleavage of structural proteins during the assembly of the head of bacteriophage T4. Nature 227, 680-685.

Lee, C. Y., Bagdasarian, M., Meng, M. H. \& Zeikus, J. G. (1990). Catalytic mechanism of xylose (glucose) isomerase from Clostridium thermosulfurogenes. Characterization of the structural gene and function of active site histidine. J Biol Chem 265, 19082-19090.

Mandel, M. \& Marmur, J. (1968). Use of ultraviolet absorbancetemperature profile for determining the guanine plus cytosine content of DNA. Methods Enzymol 12B, 195-206.
Miquel, P. (1888). Monographie d'un bacille vivant au-dela de $70{ }^{\circ} \mathrm{C}$. Ann Micrographic 1, 3.

Pikuta, E., Lysenko, A., Chuvilskaya, N., Mendrock, U., Hippe, H., Suzina, N., Nikitin, D., Osipov, G. \& Laurinavichius, K. (2000). Anoxybacillus pushchinensis gen. nov., sp. nov., a novel anaerobic, alkaliphilic, moderately thermophilic bacterium from manure, and description of Anoxybacillus flavithermus comb. nov. Int J Syst Evol Microbiol 50, 2109-2117.

Riffard, S., Lo Presti, F., Normand, P., Forey, F., Reyrolle, M., Etienne, J. \& Vandenesch, F. (1998). Species identification of Legionella via intergenic $16 \mathrm{~S}-23 \mathrm{~S}$ ribosomal spacer PCR analysis. Int $J$ Syst Bacteriol 48, 723-730.

Stackebrandt, E. \& Goebel, B. M. (1994). Taxonomic note: a place for DNA-DNA reassociation and 16S rRNA sequence analysis in the present species definition in bacteriology. Int J Syst Bacteriol 44, 846-849.

Vandamme, P., Pot, B., Gillis, M., De Vos, P., Kersters, K. \& Swings, J. (1996). Polyphasic taxonomy, a consensus approach to bacterial systematics. Microbiol Rev 60, 407-438.

Wayne, L. G., Brenner, D. J., Colwell, R. R. \& 9 other authors (1987). International Committee on Systematic Bacteriology. Report of the ad hoc committee on reconciliation of approaches to bacterial systematics. Int J Syst Bacteriol 37, 463-464. 